\title{
KOSMOPOLITYZM JAKO POPULARNA TEORIA KRYTYCZNA
}

Gerard Delanty jest profesorem socjologii i myśli społeczno-politycznej w University of Sussex. Bada takie zjawiska jak nacjonalizm, tożsamości narodowe, ideologie. Zajmuje się też socjologią historyczną i filozofią nauki. Jego dotychczasowe liczne publikacje (własne i redagowane) dotyczyły tematyki z pogranicza socjologii i nauk politycznych. Tutaj interesuje nas przede wszystkim ostatni obszar zainteresowania Gerarda Delanty'ego - teoria krytyczna. Wydał on dotychczas cztery tomy krytycznych esejów na temat Theodora Adorno oraz podręcznik dotyczący tego podejścia.

Delanty uważa, że współczesna teoria krytyczna przeszła od krytyki dominacji i ideologii, charakterystycznych dla pierwszych myślicieli z kręgu szkoły frankfurckiej, do komunikacyjnej teorii działania społecznego. Zniekształcona świadomość stała się więc ważniejsza niż świadomość fałszywa. Zdaniem Delanty'ego prace Jürgena Habermasa oraz Axela Honnetha można połączyć z tradycją kosmopolityzmu w szerokim zakresie obecną w kulturze europejskiej ${ }^{1}$. Autor The Cosmopolitan Imagination chciałby, aby jego praca stanowiła wyzwanie zarówno dla myślenia w kategoriach narodowych, jak i dla niezachwianej wiary w rynek (s. 262). Jest to podejście nowatorskie również dlatego, że dotychczas tematyka kosmopolityzmu rzadko była autotelicznym przedmiotem analizy socjologicznej. Warto przypomnieć, że hasło „kosmopolityzm" nie zostało włączone na przykład do polskiej Encyklopedii socjologii.

Adres do korespondencji: kamil.luczaj@ gmail.com; karol.kaczorowski@gmail.com

${ }^{1}$ Gerard Delanty, The Cosmopolitan Imagination: Renewal of Critical Social Theory, Cambridge University Press, Cambridge 2009, stron 296.
Kosmopolityzm, zdaniem autora, jest rodzajem nastawienia wobec świata. Głównym celem jego dzieła jest pokazanie, że w zglobalizowanej rzeczywistości powstał nowy rodzaj wyobraźni, który Delanty nazywa „wyobraźnią kosmopolityczną". Uważa, że kosmopolityzm jest dziś wyrażany raczej za pomocą , debat, narracji, form poznania, sieci komunikacyjnych, etycznych i politycznych zasad" niż poglądów poszczególnych kosmopolitów (s. 252). W tym punkcie jego argumentacja przypomina charakterystykę postmodernizmu jako „pewnej kondycji duchowej", którą przedstawił Jean-François Lyotard $^{2}$.

Wyobraźnia kosmopolityczna jest opisywana jako doświadczenie i interpretacja świata zarazem (s. 2-8). Delanty uważa, że przedstawiony przez niego kosmopolityzm ,jako podejście teoretyczne sprzyja krytycznej postawie, którą można przeciwstawić interpretatywnemu lub opisowemu nastawieniu do świata społecznego" (s. 5). Celem współczesnego kosmopolityzmu jest alternatywne odczytanie historii i rozpoznanie zróżnicowania społecznego. Delanty pisze więc o postuniwersalizmie, który choć jest formą uniwersalizmu, to jednak odnosi się z szacunkiem do innych kultur (s. 9). Współczesny kosmopolityzm postrzega kultury jako byty połączone, a nie po prostu różne (s. 73).

Zdaniem Delanty’ego, współczesną postać kosmopolityzmu dobrze opisują cztery wymiary. Pierwszy to wzrastająca liczba osób identyfikujących się raczej z tym, co globalne, niż z kontekstem lokalnym lub narodowym. Drugi obejmuje zmianę prawną, uwzględniającą Innych

2 Por. J.-F. Lyotard, Postmodernizm dla dzieci. Korespondencja 1982-1985, tłum. J. Migasiński, Aletheia, Warszawa 1998. 
i wpływ kosmopolitycznych wartości na kierunek polityki narodowej. Trzeci to wpływ globalnej polityki na politykę narodową. Ostatni zaś dotyczy dyskursywnych zmian w sferze publicznej, do których zalicza się komunikacja międzykulturowa i międzynarodowe debaty. Autor wskazuje także cztery cechy myślenia kosmopolitycznego: zdolność do relatywizacji swojej kultury i tożsamości, zdolność pozytywnego uznawania Innego, zdolność do wzajemnej oceny kultur i tożsamości oraz zdolność do utworzenia wspólnej kultury normatywnej (s. 86-87). Delanty odwołuje się przy tym do „immanentnej transcendencji”, która stanowi ważny element dyskursu tzw. IV pokolenia szkoły frankfurckiej. Axel Honneth twierdzi, że istotą tego pojęcia jest „normatywny potencjał, który w każdej społecznej rzeczywistości na nowo ukazuje swą wartość, ponieważ jest ściśle scalony ze strukturą ludzkiego układu interesów" ${ }^{3}$. Transcendencja zatem ma stać się częścią immanencji: elementem teorii społecznej powinny być przekraczające empirię roszczenia normatywne. Zdaniem Delanty'ego, perspektywa kosmopolityczna jest w stanie zrealizować takie założenie (s. 77).

Autor Wyobraźni kosmopolitycznej zasadniczą część swojego wywodu podzielił na dziewięć części. Początkowe rozdziały poświęcił przedstawieniu bogatych tradycji kosmopolityzmu w myśli społeczno-politycznej. Uważa, że grecki kosmopolityzm był uniwersalistyczny $\mathrm{i}$ jedynie $\mathrm{w}$ ograniczonym stopniu może być przydatny dla współczesnej teorii społecznej. Kosmopolityzm antyczny, etymologicznie związany z pojęciem „obywatel świata”, był jednak zawsze krytyczny wobec rzeczywistości. Cynicy bowiem zwalczali zamknięty świat greckiej polis, wraz z jej najwyższym ideałem, polegającym na poświęceniu się wspólnocie (s. 21). Delanty nie ogranicza swoich rozważań wyłącznie do świata kultury zachodniej. Pokazuje, że konfucjanizm był równie dobrym

${ }^{3}$ A. Honneth, Istota uznania, w: N. Fraser, A. Honneth (red.), Redystrybucja czy uznanie? Debata polityczno-filozoficzna, tłum. M. Bobako, Wydawnictwo Naukowe Dolnośląskiej Szkoły Wyższej Edukacji TWP, Wrocław 2005, s. 218. tłem rozwoju kosmopolityzmu jak kultura europejska.

Delanty zwraca następnie uwagę, że w okresie od Renesansu do Oświecenia kosmopolityzm i nacjonalizm nie były uważane za sprzeczne i często współwystępowały ze sobą (s. 29). „Ojciec nacjonalizmu”, Johann Gottfried Herder, interesował się między innymi wartościami uniwersalnymi we wszystkich kulturach. Jeżeli na tym etapie kosmopolityzm był przeciwstawiany państwu, to - zdaniem autora - działo się tak wyłącznie ze względu na fakt, że jego przedstawiciele byli krytycznie nastawieni do rzeczywistości politycznej (s. 37).

Wiek XIX przyniósł jednak nowe rodzaje nacjonalizmu, które zastąpiły dotychczasowy republikanizm, wypierając jednocześnie perspektywę kosmopolityczną. Wróciła ona dopiero w Manifeście komunistycznym, gdzie termin ten nie ma jednoznacznie pozytywnego wydźwięku. Karol Marks i Fryderyk Engels potępiają tam kosmopolityczny kapitał, wysoko ceniąc jednocześnie proletariat zjednoczony ponad podziałami narodowymi ${ }^{4}$. Delanty uważa, że kosmopolityzm, w nowej, zmienionej formie, pojawił się dopiero wraz ze wznowieniem idei Igrzysk Olimpijskich, ustanowieniem Nagrody Nobla i innymi kluczowymi wydarzeniami przełomu XIX i XX wieku.

Rozdział trzeci został poświęcony zagadnieniom etycznym. Delanty uważa, że globalna przemoc powoduje konieczność stworzenia nowej etyki. Polemizuje w ten sposób $z$ komunitarianami, którzy starają się wykazać brak ponadkulturowych wartości. Odwołując się do znanych koncepcji teoretycznych Jürgena Habermasa, głosi potrzebę ustanowienia „etyki dyskursywnej”. Konsensus nie miałby być jej założeniem, lecz celem (s. 97). W tworzeniu tej etyki pomóc ma światowa opinia publiczna, przeświadczenie, że „świat na nas patrzy” (s. 109).

W rozdziale czwartym Delanty obserwuje przekształcenia idei obywatelstwa i państwa. Przedstawia tam propozycję opozycyjną zarówno wobec modelu indywidualistycznego, jak

${ }^{4}$ K. Marks i F. Engels, Manifest komunistyczny, w: K. Marks i F. Engels (red.), Dzieła wybrane, t. 1, Książka i Wiedza, Warszawa 1949, s. 55. 
i komunitariańskiego. Pisze, że kosmopolityczne obywatelstwo musi pozwolić na uznawanie Innych, łącząc uniwersalne prawa jednostki z ochroną mniejszości (s. 127). Odróżnia również obywatelstwo globalne od kosmopolitycznego, które oprócz problemów globalnych zawsze widzi też kontekst lokalny.

Przedmiotem piątego rozdziału jest odniesienie propozycji „wyobraźni kosmopolitycznej" do teorii multikulturalizmu. Klasyczny multikulturalizm był oparty, zdaniem autora, na liberalnych zasadach jedności i równości. $\mathrm{Z}$ czasem nastąpiło przesunięcie nacisku $\mathrm{z}$ zasady równości na zasadę różnorodności, co spowodowało kryzys multikulturalizmu. Kryzys ten był związany ze sceptycyzmem wobec możliwości opracowania kryteriów oceny propozycji teoretycznych, gdy wszystkie wartości uznaje się za równoprawne. Chcąc przezwyciężyć tę patową sytuację, można wybrać jedną z trzech dróg. Pierwszą jest możliwość dążenia do ideału dyskursywnej sfery publicznej Jürgena Habermasa. Inną propozycją jest liberalny pragmatyzm Richarda Rorty'ego (s. 140). Kosmopolityczna wersja multikulturalizmu daje natomiast możliwość utworzenia powszechnej kultury publicznej (s. 140). Delanty argumentuje, że model kosmopolitycznego multikulturalizmu jest najbardziej wartościowy, gdyż w przeciwieństwie do modelu liberalnego nie bazuje na podkreślaniu różnic prawnych między grupami społecznymi ani nie odrzuca możliwości stworzenia wspólnej kultury. Zasadza się natomiast na dyskursywnej i deliberatywnej przemianie wszystkich grup społecznych. W dalszej części rozdziału autor celnie zauważa, że istnieje niewiele prac naukowych poświęconych wpływowi zachodniego multikulturalizmu na świat „niezachodni”. Autor wylicza również czynniki utrudniające analizę niezachodnich kultur przy zastosowaniu zachodnich ram pojęciowych (s. 153-154).

Szósty rozdział został poświęcony religii w społeczeństwach kosmopolitycznych. Autor zastanawia się, czy Europa będzie w stanie przejść od sekularnego do postsekularnego sposobu pojmowania religii. Nakreślając historię sekularyzmu, Delanty zwraca uwagę, że pojęcie to właściwie nigdy nie oznaczało całkowitego zaniku religijności. Nawet współcześnie kra- je uznawane za zsekularyzowane, jak Niemcy, Francja czy Holandia, posiadają przepisy prawne regulujące stosunki między instytucjami państwowymi a religijnymi (s. 164-168). W dziejach Europy Delanty wyróżnił: model republikański charakterystyczny dla Francji, liberalny (konstytucyjno-konserwatywny) obowiązujący w Niemczech i Holandii oraz - pozostający głównie teoretycznym postulatem - model liberalno-wspólnotowy. O ile naczelnym zadaniem pierwszego modelu jest oddzielenie religii od państwa przez relegowanie jej do sfery prywatnej, o tyle propozycja liberalna nie wyklucza możliwości pewnych przywilejów dla „oficjalnych Kościołów", jeżeli relacje z nimi są uregulowane w konstytucji. Utopijny model liberalno-wspólnotowy wspierałby zaś jak największą różnorodność etniczno-religijną społeczeństwa. Zdaniem autora, ważna rola, jaką religia odgrywa dla milionów ludzi, wymaga polityki postsekularystycznej, która przekracza te trzy warianty. Propozycja Delanty'ego odwołuje się do Habermasowskiego postulatu dopuszczenia przedstawicieli poszczególnych religii do sfery publicznej pod warunkiem wykazania przez nich woli udziału w publicznej dyskusji (s. 172-175). W przeciwieństwie do niemieckiego myśliciela autor Wyobraźni kosmopolitycznej postuluje dopuszczenie do publicznej debaty grup ekstremistycznych. Brak możliwości dyskusji z przedstawicielami kultury dominującej w danym społeczeństwie mógłby bowiem skutkować odwołaniem się imigrantów z krajów muzułmańskich do ugrupowań fundamentalistycznych lub terrorystycznych. Jako przykład kosmopolitycznego podejścia do polityki religijnej Delanty wskazuje ład powstały po porozumieniu wielkopiątkowym w Irlandii (s. 173).

W rozdziale siódmym Gerard Delanty podejmuje tematykę różnych wariantów nowoczesności. Stwierdza, że stanowią one formy translacji kulturowych, które powodują autotransformacje społeczeństw. W jego ujęciu nowoczesność nie jest zatem etapem historii, lecz procesem, który toczy się nieustannie. Brytyjski socjolog zajmuje się tu także problemem eurocentryzmu. Zjawisko to może być rozumiane na dwa sposoby: jako uznawanie wyższości kulturowej Zachodu nad resztą świata lub jako po- 
strzeganie całego globu przez pryzmat zachodnich wartości i pojęć.

Rozdziały ósmy oraz dziewiąty dotyczą Europy i modelu integracji stosowanego $\mathrm{w}$ Unii Europejskiej. Delanty traktuje go jako wzór „kosmopolityzacji" rzeczywistości społecznej. Autor Wyobraźni kosmopolitycznej w typowy dla siebie sposób rozpoczyna od zarysowania różnych wizji politycznych integracji europejskiej. Zaznacza przy tym słabość dotychczasowego sposobu prowadzenia polityki Unii, czyli kładzenie nacisku głównie na efektywność realizacji celów ekonomiczno-politycznych. Współczesne problemy państw członkowskich, między innymi te związane $z$ ratyfikacją traktatu lizbońskiego, są — zdaniem Delanty'ego - efektem zaniedbania społecznego aspektu integracji (akcentującego wartości solidarności i równości społecznej). Zagrożeniem staje się $\mathrm{w}$ tym kontekście możliwość wykorzystania owej luki przez ugrupowania antyeuropejskie i populistyczne. Natomiast dzięki promocji ponadnarodowej tożsamości europejskiej integracja społeczna może wzrosnąć (s. 214).

Następnie Delanty wylicza historyczne koncepcje Europy i jej granic, podkreślając, że wraz z traktatem z Maastricht (1993) dominująca stała się polityczna definicja Europy, przesuwająca aspekty geograficzne i kulturowe na dalszy plan (s. 232). Jego zdaniem, w XXI wieku adekwatniejsze byłoby jednak postrzeganie Europy właśnie według tych kryteriów. W dalszej części rozdziału znajdujemy omówienie koncepcji postzachodniej Europy. Unia Europejska nie ogranicza się już do terenów na zachód od Odry, lecz współtworzą ją również państwa środkowo-wschodniej i południowo-wschodniej Europy, które są kulturowymi spadkobiercami wpływów Imperium Bizantyjskiego i Osmańskiego. Unia zaczyna mieć więc bardziej kosmopolityczny charakter (s. 243). Konkluzja rozdziału jest optymistyczna: Unia Europejska jest skłonna przyjąć kosmopolityczną politykę, a wzajemny wpływ państw tworzących jej centrum i peryferie czyni ich relacje bardziej egalitarnymi.

W podsumowaniu książki autor podkreśla po raz kolejny wagę heglowsko-marksowskiego pojęcia immanentnej transcendencji oraz tworzenia „międzynarodowej umysłowości”, o któ- rej pisał George Herbert Mead (s. 252). Wskazuje także na przejmowanie idei kosmopolityzmu przez niezachodnie państwa i organizacje. Uważa, że w międzynarodowych organizacjach, takich jak ONZ czy ASEAN, tkwi potencjał wspierania dialogu międzykulturowego. Wciąż jednak wiele pozostaje do zrobienia, aby kosmopolityczne podejście do polityki międzynarodowej mogło zostać zrealizowane (s. 262).

Zarysowawszy główne wątki recenzowanego dzieła, możemy powrócić do założeń, które Gerard Delanty postawił przed swoją pracą. Stajemy tym samym wobec pytań o to, czy jego koncepcja jest faktycznie wyzwaniem dla państwa narodowego i wiary w rynek, a także w jaki sposób wyraża się jej „krytycyzm”. W pierwszym przypadku Wyobraźnia kosmopolityczna nie wnosi wiele nowego. Rzeczywiście, globalizacja wpłynęła na redefinicję różnych struktur na poziomie narodowym, jednak nie sposób uznać, że jest to konstatacja oryginalna. Ponadto wizja Delanty'ego wydaje się zbyt idealistyczna. Kosmopolityczny stan ducha, manifestujący się w pełnym uznaniu odmienności i łączeniu globalności z lokalnością, jest raczej postulatem niż opisem współczesnych społeczeństw. Dużo lepiej autor radzi sobie $\mathrm{z}$ wyzwaniem, jakim jest przeciwstawienie się hegemonii rynku. Pokazuje, że neoliberalna polityka nie jest ani końcem historii, ani też jedynym słusznym rozwiązaniem. Gerard Delanty w interesujący sposób krytykuje rozmaite współczesne teorie, takie jak „zderzenie cywilizacji” Samuela Huntingtona, oraz opisuje wpływ kosmopolityzmu na społeczeństwa niezachodnie. Wyobraźnia kosmopolityczna jest więc ciekawą propozycją z dziedziny polityki integracyjnej, gdyż autor kładzie nacisk na problematykę solidarności, sprawiedliwości społecznej i różnorodności kulturowej. Ta tematyka wydaje się niedostatecznie opisana w analizach neoinstytucjonalnych.

Dochodzimy w ten sposób do najważniejszego pytania: czy rzeczywiście kosmopolityzm może być rozumiany jako środek na odrodzenie teorii krytycznej? Tutaj sprawa bardzo się komplikuje. Choć sama nazwa teorii krytycznej pojawia się kilkakrotnie $\mathrm{w}$ toku wywodu, to jest ona używana dość swobodnie. Janusz Mucha mówi w tym kontekście o uprawianiu socjologii kry- 
tycznej „W sposób potoczny” ${ }^{5}$. Czytając książkę Delanty'ego trudno oprzeć się wrażeniu, że miano teorii krytycznej nie do końca odpowiada przedstawionemu w niej zestawowi poglądów. Autor konsekwentnie unika odniesień do dawniejszych elementów tradycji socjologii krytycznej i radykalnej. Jego praca obfituje za to w różnego rodzaju inne konteksty. Często pojawiają się zgoła niekrytyczni teoretycy globalizacji, tacy jak Manuel Castells czy Ulrich Beck. Dużo jest także odwołań do wielkich dzieł filozoficznych z różnych epok, choć nazwisko Herberta Marcusego nie pojawia się bodaj wcale. Wyobraźnia kosmopolityczna wydaje się więc bardziej rozwinięciem teorii kosmopolityzmu niż teorii krytycznej.

Nawiązując do aktualnych wydarzeń politycznych oraz komentując różne podejścia do zróżnicowania kulturowego i polityki integra-

${ }^{5} \mathrm{~J}$. Mucha, Socjologia jednostek $i$ teoria krytyczna. Konferencja lizbońska o aktualnych debatach w socjologii teoretycznej, „Studia Humanistyczne” 2010, nr 8 . cyjnej Delanty dokonał interesującej diagnozy sytuacji społeczno-politycznej współczesnego świata. Jednakże omawiane przezeń rozwiązania problemów w znacznym stopniu cechuje ogólność i teoretyczna abstrakcja. „Wyobraźnia kosmopolityczna" pozostaje więc jedynie wyobraźnią, gdyż w pracy tej brakuje konkretnych propozycji kosmopolitycznego działania.

Opinia, że dzieło ma zarówno plusy i minusy, nie jest szczególnie oryginalna, jednak treść pracy Delanty'ego właśnie taką opinię narzuca. Choć Wyobraźnia kosmopolityczna nie może być uznana za dzieło krytyczne tout court, to wskazuje pewne kierunki potencjalnej krytyki zglobalizowanego społeczeństwa, czego unika na przykład Manuel Castells. Wobec kryzysu współczesnej socjologii krytycznej, który jest szczególnie widoczny w Polsce, warto przyjrzeć się bliżej ideom zaproponowanym przez Delanty'ego. Naszą opinię na temat recenzowanego dzieła można podsumować więc bardzo krótko: jest to interesujący głos w sprawie zglobalizowanego świata, jednak podtytuł dodany został mocno na wyrost. 